\title{
Kedudukan Anak dari Perkawinan Berbeda Agama Menurut Hukum Perkawinan Indonesia
}

\author{
Fitria Agustin \\ Program Studi Ilmu Hukum, Universitas Serang Raya \\ Email : fitriahisaan@gmail.com
}

\begin{abstract}
Article 2 paragraph (1) of Law Number 1 Year 1974 contains provisions that marriage shall be considered valid if done according to the law of their respective religion and belief. The above provision implies no marriage outside the law of each of his or her religion and belief. Intermarriages between people of different religions will obviously cause problems as a result of the law of their marriage, most of which include the rights and duties of each husband and wife, property in marriage, as well as the position of the child in a marriage relationship. Problems will arise when the child has been born starting from the pattern of upbringing until when the child is adult and ably performs legal acts such as marriage, inheritance, and so forth. This research is intended to get answers to the problems: (1) How the position of the Child from Marriage parents of different religions? 2) How does the child's relationship with her parents' parent if the child chooses a religion differently from both parents? The invention of the answer to this question is pursued by the Empirical Normative Legal Research Method. The law acts as a Norm (Legislation), with due regard to social reality. The results of the study are: (1) The marriage of religious differences according to the Marriage Law is considered invalid as well as the child born of the Marriage. (2) A child born of a different religious marriage only has a nasab with his mother.
\end{abstract}

Keywords: marriage, religious difference, the position of the child

\begin{abstract}
Abstrak
Pasal 2 ayat (1) UU Nomor 1 Tahun 1974 memuat ketentuan bahwa perkawinan dianggap sah apabila dilakukan menurut hukum masing-masing agamanya dan kepercayaannya itu. Ketentuan di atas mengisyaratkan tidak ada perkawinan di luar hukum masing-masing agamanya dan kepercayaanya itu. Perkawinan antar orang yang berlainan agama jelas akan menimbulkan permasalahan sebagai akibat hukum dari perkawinan mereka, yang sebagian besar meliputi hak dan kewajiban masing-masing suami dan istri, harta dalam perkawinan, maupun kedudukan anak dalam hubungan perkawinan. Permasalahan akan timbul ketika anak telah dilahirkan dimulai dari pola pengasuhan sampai ketika anak dewasa dan cakap melakukan perbuatan hukum seperti menikah, menerima warisan, dan sebagainya. Penelitian ini ditujukan agar mendapat jawaban atas permasalahan : (1) Bagaimana kedudukan Anak dari Perkawinan orangtuanya yang berbeda agama ? 2) Bagaimana hubungan anak dengan nasab orangtuanya jika anak memilih agama berbeda dengan kedua orangtuanya? Penemuan jawaban atas pertanyaan ini ditempuh dengan Metode Penelitian Hukum Normatif Empiris. Hukum bertindak sebagai Norma (Perundang-undangan), dengan memperhatikan kenyataan sosial. Hasil Penelitian adalah : (1) Perkawinan beda agama menurut Undang-undang Perkawinan dianggap tidak sah begitupula anak yang dilahirkan dari Perkawinan tersebut. (2) Anak yang dilahirkan dari perkawinan beda agama hanya memiliki nasab dengan ibunya.
\end{abstract}

Kata Kunci: perkawinan, beda agama, kedudukan anak 


\section{PENDAHULUAN}

Dalam Pasal 1 Undang-Undang Nomor 1 Tahun 1974 tentang Perkawinan ditegaskan bahwa : Perkawinan ialah ikatan lahir bathin antara seorang pria dengan seorang wanita sebagai suami istri dengan tujuan membentuk keluarga (rumah tangga) yang bahagia dan kekal berdasarkan Ketuhanan Yang Maha Esa. Dimulai dengan definisi ini, maka perkawinan tetap diharapkan mengacu pada asas-asas Ketuhanan yang Maha Esa. Dalam hal ini kedudukan Hukum Islam yang dialurkan dalam Undang-Undang Perkawinan mengatur bagaimana momentum Perkawinan dilaksanakan.

Memperbincangan kedudukan hukum Islam dalam Undang-Undang Dasar 1945 dapat dilihat secara khusus dipahami dari Pasal 29 ayat (1) UUD 1945. Dalam Pasal 29 ayat (1) ini dinyatakan bahwa negara berdasarkan Ketuhanan Yang Maha Esa. Kaidah fundamental dalam pasal ini dapat ditafsirkan diantaranya adalah : Pertama, dalam negara Republik Indonesia ini tidak boleh ada atau berlaku hukum yang bertentangan dengan kaidah-kaidah agama yang berlaku bagi pemeluk agama yang berlaku di Indonesia. Kedua, negara wajib menjalankan syariat semua agama yang berlaku di Indonesia, bilamana untuk menjalankan syariat tersebut memerlukan bantuan kekuasaan negara. Ini berarti bahwa negara wajib mengatur dan menjalankan hukum yang berasal dari ajaran agama untuk kepentingan bangsa Indonesia. Ketiga, syariat yang pelaksanaannya tidak memerlukan bantuan negara dapat dijalankan sendiri oleh pemeluk agama yang bersangkutan. Ini berarti hukum yang berasal dari agama yang berlaku di Indonesia yang dapat dijalankan sendiri oleh pemeluknya menurut kepercayaan pemeluk agama masing-

${ }^{1}$ Abdul Halim, Politik Hukum Islam di Indonesia : Kajian Posisi Hukum Islam dalam Politik Hukum Pemerintahan Orde Baru dan Era Reformasi ; Seri Disertasi, Badan Litbang dan Diklat Departemen Agama RI, 2008, hlm. 131 masing seperti bidang ibadah. ${ }^{1}$ Setiap warganegara mempunyai hak-hak yang wajib diakui (recognized) oleh negara dan wajib dihormati (respected), dilindungi (protected), dan difasilitasi (ficilitated), serta dipenuhi (fulfilled), oleh Negara. ${ }^{2}$

Menurut Masykuri Abdillah, eksistensi Hukum Islam di Indonesia mempunyai 2 bentuk : 1) Sebagai hukum formal yang dilegislasikan sebagai hukum positif untuk umat Islam di Indonesia.; 2) Sebagai hukum normatif yang diimplementasikan secara sadar oleh umat Islam. ${ }^{3}$ Negara kita, sesuai dengan yang difalsafahkan dalam sila 1 Pancasila adalah Negara dengan berdasarkan Ketuhanan Yang Maha Esa. Maka sepatutnya kita memahami bahwa urusan dalam Perkawinan yang diatur negara tidak boleh berlepas dari tuntunan agama. Perkawinan mempunyai hubungan yang erat sekali dengan agama sehingga perkawinan bukan saja mempunyai unsur lahir/jasmani, tetapi juga unsur bathin/rohani.

Yang dimaksud dengan "Perkawinan antar Orang yang Berlainan Agama" di sini ialah Perkawinan orang Islam (pria/wanita) dengan orang bukan Islam (pria/wanita). Dalam hal ini, islam membedakan hukumnya sebagai berikut : ${ }^{4}$

1. Perkawinan antar seorang pria Muslim dengan wanita Musyrik

2. Perkawinan antar seorang pria Muslim dengan wanita Ahlul Kitab

3. Perkawinan antar seorang wanita Muslimah dengan seorang pria Non Muslim

Pemerintah Indonesia sebagai penyelenggara Negara dalam setiap penggalan sejarah rezimnya selalu mengakui beberapa agama dan kepercayaan yang boleh hidup dan berkembang secara terbatas,

2 Rokilah, Implikasi Kewarganegaraan Ganda bagi Warganegara Indonesia, Jurnal Ilmu Hukum “Ajudikasi", Vol. 1 No. 2, Serang-Banten : Desember 2017, hlm. 55

${ }^{3}$ Ibid., hlm. 132

${ }^{4}$ Masjfuk Zuhdi, Masail Fiqhiyah, CV. Haji Mas Agung, Jakarta, 1998, hlm. 4 
bahkan bertanggung jawab atas eksistensi agama, kehidupan beragama, dan kerukunan hidup beragama. Dalam kaitan itu, sekurangkurangnya terdapat tujuh aturan perundangundangan terkait yang telah dilaksanakan. Eksistensi peraturan perundang-undangan tersebut, selain berfungsi sebagai pelindung kesucian agama, ketentraman hidup beragama, dan pendorong bagi umat beragama untuk menjalankan agamanya, sekaligus merupakan pembeda dengan sistem yang berlaku di negara lain. ${ }^{5}$

Inilah yang menjadi landasan mengapa negara harus mempertimbangkan kaidah agama dalam penerapan hukumnya termasuk dalam hal perkawinan. Masalah dalam perkawinan yang berbeda agama akan menimbulkan akibat hukum bagi kedudukan anak. Dalam hal ini bagaimana status perkawinan pemeluk agama yang berbeda ini? Bagaimana pula kedudukan anak yang dilahirkan sebagai akibat hukum dari perkawinan berbeda agama ini? Bagaimana kedudukan nasab jika anak memilih salah satu agama orangtuanya atau memilih agama yang berbeda dengan agama orang tuanya? Semua pertanyaan di atas adalah mungkin dipertanyakan jika terjadi perkawinan dimaksud.

Dalam hal ini tinjauan penulis hanya menajam pada landasan dalam UndangUndang Perkawinan saja yaitu UndangUndang Nomor 1 Tahun 1974 tentang Perkawinan, dimana dalam hal ini Perkawinan Berbeda Agama hanya menunjuk pada Pemeluk Agama Islam yang menikah dengan Pemeluk Agama selain Islam. Adapun pemeluk Agama selain Islam yang kemudian melakukan perkawinan dengan pemeluk agama lain diluar agamanya tidak dibahas pada penulisan ini. Hal ini untuk menghindari kerancuan dan kesalahpahaman rujukan dalam kaidah agama.

Berdasarkan uraian latar belakang masalah di atas, maka dirumuskan masalah mengenai kedudukan Anak dari Perkawinan

\footnotetext{
5 M. Saerozi, Bila Negara Mengatur Agama, Jurnal
} Studi Islam dan Masyarakat "Ulumuna", Institut orangtuanya yang berbeda agama serta hubungan anak dengan nasab orangtuanya jika anak memilih agama berbeda dengan kedua orangtuanya.

\section{KERANGKA KONSEPTUAL}

Jenis penelitian yang digunakan adalah Penelitian Pustaka (Library Research) yang bersifat normatif yaitu dengan melaksanakan penelusuran terhadap bahan-bahan pustaka berupa literatur dan Perundang-undangan yang berhubungan dengan kedudukan anak akibat perkawinan orangtuanya yang berbeda agama. Jenis data yang digunakan adalah data sekunder yang tersusun dalam bentuk literatur yang terdiri dari buku-buku, jurnal-jurnal, perundang-undangan, maupun tulisan-tulisan lainnya yang berkaitan dengan kedudukan anak akibat dari perkawinan orangtuanya yang berbeda agama.

Teknik analisis yang dipergunakan adalah Analisis Kualitatif yaitu dengan memperhatikan keterkaitan data dengan permasalahan, maupun keterkaitan data dengan data lain sehingga diperoleh kesimpulan yang benar. Penarikan kesimpulan dilakukan dengan memulai dari hal-hal yang bersifat umum untuk kemudian diterapkan pada hal yang bersifat khusus.

Metode yang digunakan dalam penelitian ini adalah Metode Penelitian Hukum Normatif Empiris, dimana Hukum bertindak sebagai Kaidah / Norma. Dalam hal ini yang menjadi titik fokus adalah Hukum sebagai Normwissenschaft yang menitikberatkan pada Hukum sebagai Tata Perundang-Undangan yang diberlakukan sebagai Hukum Positif di Indonesia. Analisa dititikberatkan pada peraturan perundang-undangan yang menjadi koseptual terhadap masalah yang terjadi dan bagaimana penerapannya.

Secara historis berlaku berbagai hukum perkawinan bagi berbagai golongan

Agama Islam Negeri Mataram, Vol. VIII, Edisi 12, No. 2, Juli-Des 2003, hlm. 264 
warganegara dan berbagai daerah seperti berikut : ${ }^{6}$

1) Bagi orang-orang Indonesia Asli yang beragama Islam berlaku hukum agama yang telah diresipir dalam Hukum Adat

2) Bagi orang-orang Indonesia lainnya berlaku Hukum Adat

3) Bagi orang-orang Indonesia Asli yang beragama Kristen berlaku Huweliksordonantie Christen Indonesia (S. 1933 No. 74)

4) Bagi orang Timur Asing Cina dan Warga Negara Indonesia keturunan Cina berlaku ketentuan-ketentuan Kitab UndangUndang Hukum Perdata dengan sedikit perubahan.

5) Bagi orang-orang Timur Asing lainnya dan Warga Negara Indonesia keturunan Timur Asing lainnya tersebut berlaku Hukum Adat mereka;

6) Bagi orang-orang Eropa dan Warga Negara Indonesia keturunan Eropa dan yang disamakan dengan mereka berlaku Kitab Undang-Undang Hukum Perdata Dalam Pasal 1 Undang-Undang Nomor 1 Tahun 1974 tentang Perkawinan sudah menegaskan bahwa Perkawinan adalah ikatan lahir bathin antara seorang pria dengan seorang wanita sebagai suami isteri dengan tujuan membentuk keluarga (rumahtangga) yang bahagia dan kekal berdasarkan Ketuhanan Yang Maha Esa. Ditegaskan dalam penjelasan bahwa sebagai negara yang berdasarkan Ketuhanan Yang Maha Esa, perkawinan mempunyai hubungan yang erat sekali dengan agama sehingga perkawinan bukan saja mempunyai unsur lahir / jasmani, tetapi juga unsur bathin / rohani.

Beberapa asas yang tercantum dalam Undang-Undang Nomor 1 Tahun 1974 tentang Perkawinan adalah sebagai berikut :

1) Tujuan Perkawinan adalah membentuk keluarga yang bahagia dan kekal. Masingmasing pihak yaitu suami dan istri perlu saling membantu dan melengkapi agar tercapai kesejahteraan spirituil dan materiil.

2) Suatu perkawinan adalah sah bilamana dilakukan menurut hukum masing-masing agamanya dan kepercayaannya itu, dan harus dicatat menurut peraturan perundangan yang berlaku.

3) Perkawinan menganut asas monogami, namun apabila dikehendaki oleh yang bersangkutan, karena hukum dan agama dari yang bersangkutan mengizinkannya, seorang suami dapat beristri lebih dari seorang, setelah memenuhi persyaratan tertentu dan diputuskan oleh pengadilan.

4) Batas umur untuk kawin bagi pria ialah 19 (sembilan belas) tahun, dan bagi wanita 16 (enam belas) tahun

5) Untuk mencapai tujuan perkawinan, maka dianut prinsip mempersulit terjadinya perceraian, yaitu dengan menyatakan alasan-alasan tertentu serta harus dilakukan di depan sidang Pengadilan

6) Hak dan kedudukan isteri adalah seimbang dengan hak dan kedudukan suami.

Selanjutnya yang menjadi syarat-syarat Perkawinan seperti yang diatur dalam Pasal 6 sampai dengan Pasal 11 Undang-Undang Nomor 1 Tahun 1974 adalah sebagai berikut :

1) Adanya persetujuan kedua calon mempelai

2) Adanya izin dari orangtua / wali bagi calon mempelai yang belum berumur 21 tahun

3) Umur calon mempelai pria sudah mencapai 19 tahun dan mempelai wanita sudah mencapai 16 tahun

4) Antara kedua calon mempelai tidak ada hubungan darah / keluarga yang dilarang kawin

5) Tidak terikat hubungan perkawinan dengan oranglain

6) Tidak bercerai untuk kedua kali dengan suami atau itri yang sama, yang hendak dikawini

\footnotetext{
${ }^{6}$ Rosnidar Sembiring, Hukum Keluarga (Harta-harta Benda dalam Perkawinan), PT. RajaGrafindo Persada, Jakarta, 2016, hlm. 41-42
} 
7) Bagi seorang wanita (janda) tidak dapat kawin lagi sebelum lewat waktu tunggu

Adapun Akibat Hukum dari Perkawinan adalah sebagai berikut :

1) Hak dan Kewajiban Suami Isteri (Pasal 30 sampai dengan Pasal 34), bahwa kedudukan suami isteri adalah seimbang, dengan suami sebagai kepala keluarga dan isteri sebagai ibu rumahtangga dengan kewajiban yang telah ditentukan, dan masing-masing pihak berhak untuk melakukan perbuatan hukum. Dalam hal ini jika suami dan isteri melalaikan kewajibannya, maka masing-masing dapat mengajukan gugatan ke pengadilan.

2) Harta benda dalam perkawinan (Pasal 35), bahwa akan terjadi apa yang disebut sebagai harta bersama sepanjang kedua belah pihak baik suami dan isteri tidak mengadakan pemisahan harta secara khusus. Yang dimaksud harta bersama adalah harta benda yang diperoleh selama perkawinan. Sedang harta yang dibawa oleh masing-masing pihak disebut harta bawaan, dan dalam hal ini masing-masing pihak mempunyai hak sepenuhnya untuk melakukan perbuatan hukum mengenai harta bendanya.

3) Kedudukan anak yang dilahirkan dalam atau sebagai akibat perkawinan yang sah (Pasal 42), bahwa anak yang sah ini memiliki hak waris atas harta kedua orang tuanya.

Pasal 3 dalam Kompilasi Hukum Islam juga menyebutkan tujuan dari perkawinan menurut Hukum Islam yaitu untuk mewujudkan kehidupan rumah tangga yang sakinah, mawaddah dan rahmah.

\footnotetext{
Salim H.S. dan Erlies Septiana Nurbaini, Perbandingan Hukum Perdata (Comparative Civil Law), PT. RajaGrafindo Persada, Jakarta, 2015, hlm. 149
}

\section{PEMBAHASAN \\ Kedudukan Perkawinan Berbeda Agama menurut Hukum Perkawinan Indonesia}

Momentum Perkawinan dikatakan sah, apabila : ${ }^{7}$

1) Telah dilangsungkan menurut hukum agama atau kepercayaannya masingmasing-masing

2) Dicatat menurut peraturan perundang-undangan

Tujuan diadakan ketentuan Pasal 2 ayat (1) Undang-Undang Nomor 1 Tahun 1974 adalah untuk menghindari konflik hukum antar hukum adar, hukum agama dan hukum antar golongan. ${ }^{8}$

Pasal 1 Undang-Undang Nomor 1 Tahun 1974 tentang Perkawinan memberikan definisi bahwa Perkawinan adalah ikatan lahir batin antara seorang pria dengan seorang wanita sebagai suami -istri dengan tujuan membentuk keluarga (rumah tangga yang bahagia) dan kekal berdasarkan Ketuhanan Yang Maha Esa. Berdasarkan pengertian tersebut, terdapat 5 (Lima) unsur dalam Perkawinan, yaitu : ${ }^{9}$

1) Ikatan Lahir Batin

2) Antara seorang pria dengan seorang wanita

3) Sebagai suami istri

4) Membentuk keluarga (rumah tangga) yang bahagia dan kekal

5) Berdasarkan Ketuhanan Yang Maha Esa Menurut Pasal 1 Undang-Undang Nomor 1 Tahun 1974 tentang Perkawinan merumuskan, bahwa ikatan suami istri berdasarkan Ketuhanan Yang Maha Esa, perkawinan merupakan perikatan yang suci. Perikatan tidak dapat melepaskan dari agama yang dianut suami-istri. Hidup bersama suamiistri dalam perkawinan tidak semata-mata untuk tertibnya hubungan seksual tetap pada pasangan suami-istri, tetapi dapat membentuk rumahtangga yang bahagia, rumahtangga yang rukun, aman dan harmonis antara suami-istri.

\footnotetext{
${ }^{8}$ Ibid., hlm. 150

${ }^{9}$ Rosnidar Sembiring, Op. Cit., hlm. 42-43
} 
Perkawinan salah satu perjanjian suci antara seorang laki-laki dengan seorang perempuan untuk membentuk keluarga bahagia. ${ }^{10}$

Salah satu asas yang tercantum dalam Undang-Undang Perkawinan adalah Perkawinan hanya sah bilamana dilakukan menurut hukum masing-masing agamanya dan kepercayaannya. Artinya, Perkawinan akan dianggap sah bilamana perkawinan itu dilaksanakan menurut hukum agama atau kepercayaan agama yang dianut oleh calon mempelai. Kedua calon mempelai harus seagama atau seiman, kecuali hukum agamanya atau kepercayaannya itu menentukan lain. (Prinsip pada Pasal 2 ayat (1) Undang-Undang Perkawinan). ${ }^{11}$

Ibnu Hazm berpendapat bahwa tidak dihalalkan bagi seorang wanita muslimah menikahi seorang lelaki yang tidak beragama Islam. Tidak pula dihalalkan bagi seorang kafir untuk memiliki seorang hamba sahaya yang muslim dan juga seorang budak wanita muslimah. ${ }^{12}$ Al Imam Abul A'la al Maududi menyatakan bahwa sesungguhnya bahwa perkawinan dengan orang-orang nonmuslim, walaupun dibolehkan bagi lelaki muslimin dengan hukum makruh, disamping ada juga sebagian ulama yang berpendapat hukumnya haram, tapi yang pasti ulama sepakat bahwa perkawinan itu diharamkan bagi wanita muslimah selamanya. ${ }^{13}$

Bagi gereja Khatolik, perkawinan antara seseorang yang beragama Khatolik dengan orang yang bukan Khatolik, dan tidak dilakukan menurut hukum agama Khatolik dianggap tidak sah. ${ }^{14}$ Perkawinan antara pemeluk agama yang berbeda dimana salah satu calon mempelai beragama Hindu tidak diperbolehkan dan Pedande / Pendeta akan menolak untuk mengesahkan perkawinan tersebut. $^{15}$ Majelis Ulama Indonesia (MUI)

\footnotetext{
${ }^{10}$ Ibid., hlm. 43

${ }^{11}$ Ibid., hlm. 51

12 Abdul Muta'al al Jabri, Apa Bahayanya Menikah dengan Wanita Nonmuslim? Tinjauan Fiqh dan Politik, Gema Insani Press, Jakarta, 2003, hlm. 22

13 Ibid., hlm. 27
}

DKI Jakarta memfatwakan tentang Hukum Perkawinan antara Pemeluk Agama Islam (muslim) dengan Pemeluk Agama Lain (non muslim), dengan Fatwa Nomor : 13 / Fatwa / MUI-DKI / II / 2000 yang menyempurnakan atas seruan MUI DKI Jakarta tentang Perkawinan Antar Agama, tanggal 26 Muharram 1407 H / 30 September 1986, sebagai berikut : ${ }^{16}$

1. Bahwa perkawinan seorang pemeluk agama Islam laki-laki (muslim) dengan perempuan musyrikah (mengakui banyak Tuhan) atau perkawinan seorang pemeluk agama Islam perempuan (muslimah) dengan lakilaki musyrik adalah haram dan tidak sah. Hal ini didasarkan pada firman Allah SWT dalam Al Quran surat Al Baqarah ayat 221 yang artinya :

"Dan janganlah kamu nikahi wanitawanita musyrik, sebelum mereka beriman. Sesungguhnya wanita budak yang mukmin lebih baik dari wanita musyrik, walaupun dia menarik hatimu. Dan janganlah kamu menikahkan orang-orang musyrik (dengan wanita-wanita mukmin) sebelum mereka beriman. Sesungguhnya budak yang mukmin lebih baik dari orang musyrik walaupun dia menarik hatimu. Mereka mengajak ke neraka, sedang Allah mengajak ke surga dan ampunan dengan izin-Nya. Dan Allah menerangkan ayat-ayatNya (perintah-perintahNya) kepada manusia supaya mereka mengambil pelajaran (Q.S. Al Baqarah, 2 : 221)

Abdurrahman al Jaziry dalam Kitab Al Fiqh 'Ala al Madzabihib al Arba'ah

\footnotetext{
${ }^{14}$ O.S. Eoh, Perkawinan antar Agama dalam Teori dan Praktek, PT. RajaGrafindo Persada, Jakarta, 2001, hlm. 119

15 Ibid., hlm. 125

${ }^{16}$ Majelis Ulama Indonesia, Fiqh Indonesia (Himpunan Fatwa-fatwa Aktual), Editor : M. Hamdan Rasyid, Al Mawardi Prima, Jakarta, 2003, hlm. 171
} 
(Beirut : Dar al Fiqr, 1995), juz ke 4, halaman 75-76, menyatakan sebagai berikut : ${ }^{17}$

"Dan tidak halal bagi seorang muslimah kawin dengan laki-laki ahli kitab, sebagaimana juga tidak halal dengan laki-laki (bukan muslim) lainnya, karena syarat sah nya perkawinan seorang muslimah adalah calon suami harus laki-laki muslim. Dalilnya ialah firman Allah Subhanahu Wa Ta'ala yang artinya : \{dan janganlah kamu kawini wanita-wanita musyrik hingga mereka beriman \} dan firmanNya yang ditujukan kepada laki-laki : \{dan janganlah kamu kawinkan laki-laki musyrik (dengan wanita muslim) hingga mereka beriman\}. Kedua ayat ini menegaskan bahwa tidak halal bagi laki-laki muslim mengawini wanita musyrik dan tidak halal bagi wanita muslimah mengawini laki-laki musyrik dalam keadaan bagaimanapun, kecuali setelah mereka beriman (masuk Islam)."

2. Wanita muslimah, haram dan tidak sah secara mutlak menikah dengan lakilaki kafir, baik musyrik, ahli kitab (Yahudi dan Nasrani) maupun yang lain. Jika dipaksakan, maka pernikahannya batal dan tidak sah. Jika mereka melakukan hubungan suamiisteri, maka hukumnya haram. Hal ini didasarkan pada firman Allah dalam Al Quran surat Al Mumtahanah ayat 10 yang artinya : ${ }^{18}$

"Apabila kamu mengetahui bahwa mereka benar-benar wanita mukmin (muslim), maka janganlah kamu mengembalikan mereka kepada suaminya (yang non muslim); karena mereka (wanita mukmin/muslim) itu tidak halal (menjadi isteri) bagi mereka yang bukan muslim; sedang mereka (yang bukan muslim) pun tidak halal (menjadi suami) bagi mereka (wanita mukmin/muslim)" (Q.S. Al Mumtahanah, $60: 10$ )

3. Dalam keadaan tertentu, seorang pria muslim diperbolehkan menikah dengan wanita ahli kitab (Yahudi dan Nasrani) dengan syarat-syarat yang sangat ketat. Hal ini didasarkan pada firman Allah dalam Al Quran surat Al Maa'idah ayat 5 yang artinya : ${ }^{19}$

"Pada hari ini dihalalkan bagimu yang baik-baik. Makanan (sembelihan) orang-orang yang diberi alkitab itu halal bagimu, dan makanan kamu halal pula bagi mereka. (Dan dihalalkan mengawini) wanita-wanita yang menjaga kehormatan diantara wanita-wanita yang beriman dan wanita-wanita yang menjaga kehormatan diantara orang-orang yang diberi Alkitab sebelum kamu, bila kamu telah membayar maskawin mereka dengan maksud menikahinya, tidak dengan maksud berzina dan tidak (pula) menjadikannya gundik-gundik. Barangsiapa yang kafir sesudah beriman (tidak menerima hukumhukumIslam) maka hapuslah amalannya dan ia dihari akhirat termasuk orang-orang merugi." (Q.S. Al Maa'idah, 5 : 5)

Adapun syarat-syarat yang harus dipenuhi oleh seorang pria yang ingin menikah dengan wanita ahli kitab (Yahudi dan Nasrani) adalah sebagai berikut :

a. Pernikahan itu harus dilakukan berdasarkan syari'at Islam dengan memenuhi syarat-syarat dan rukun-

\footnotetext{
${ }^{17}$ Ibid., hlm. 172
}

${ }^{18}$ Ibid., 174

${ }^{19}$ Ibid., 178 
rukun pernikahan yang disebutkan dalam kitab-kitab fiqh. Seperti adanya calon suami, calon isteri, wali dan dua orang saksi yang beragama Islam dan bersifat adil serta ijab qabul. Disamping itu harus dicatat pada Kantor Urusan Agama (KUA) kecamatan setempat sesuai dengan ketentuan perundang-undangan yang berlaku. Jika pernikahan dilakukan di gereja di hadapan pastur yang memberkatinya atau hanya dicatat di Kantor Catatan Sipil, maka pernikahannya tidak sah.

b. Calon suami berkeyakinan, bahwa ia tidak akan terpengaruh dengan agama isteri, sehingga dia tidak akan murtad atau berpindah ke agama isteri. Karena agama Islam mewajibkan kepada umatnya untuk mempertahankan agama Islam hingga akhir hayat. (Q.S. Ali Imran, $3:$ 102)

c. Calon suami (pria muslim) benarbenar yakin bahwa ia akan mampu memenuhi kewajibannya sebagai seorang ayah yang beragama Islam, termasuk dalam mendidik anakanaknya sesuai dengan ajaran Islam, sehingga mereka akan tumbuh dan berkembang menjadi muslim dan muslimah yang taat. Karena agama Islam mewajibkan kepada umatnya untuk mendidik anak-anaknya sehingga mereka menjadi muslimin dan muslimat yang taat dan akhirnya selamat serta terlindung dari siksa api neraka. (Q.S. At Tahrim, $66: 6$ )

d. Calon suami (pria muslim) benarbenar yakin bahwa dia akan mampu memenuhi kewajibannya sebagai seorang suami, termasuk dalam menggauli isteri dengan baik (mu'asyarah bil ma'ruf), sehingga isteri mempunyai kesan positif terhadap ajaran-ajaran agama Islam yang tercermin dari sikap dan perilaku suami, yang akhirnya diharapkan isteri dengan kesadaran sendiri, tanpa paksaan siapapun bersedia memeluk agama Islam.

Imam Syafi'i meriwayatkan bahwa Atha berkata : ${ }^{20}$

"Orang-orang Nasrani Arab

bukanlah Ahli Kitab. Yang

dikatakan Ahli Kitab hanyalah mereka yang berasal dari Bani Israel dan orang-orang yang diberikan kepada mereka kitab Taurat dan Injil. Adapun orang yang masuk kepada agama mereka, tidak dianggap sebagai golongan mereka (Ahli Kitab)."

Selain itu, Imam Syafi'i. Ulama Malikiyah dan Hanafiyah telah menyatakan bahwa orang-orang Ahli Kitab adalah orang-orang musyrik (al Ahkam Ibnu Hazm, Juz 2, halaman 148). ${ }^{21}$

4. Jika pria muslim yang hendak menikah dengan Ahli Kitab (Yahudi atau Nasrani) tidak mampu memenuhi syarat-syarat di atas, maka haram baginya menikahi wanita non muslim, apalagi jika mafsadah (bahaya) nya jelas-jelas lebih besar daripada manfaatnya.

5. Sehubungan dengan fatwa ini, Komisi Fatwa MUI DKI Jakarta menyerukan kepada para pemuda muslim dan muslimah agar tidak berpacaran apalagi menikah dengan orang-orang non muslim.

6. Apabila ada seorang pria non muslim menyatakan ingin masuk Islam karena hendak mengawini seorang wanita muslimah, maka hendaknya wali wanita tersebut membuat suatu perjanjian kawin yang menyatakan, bahwa jika suami murtad dari agama 
Islam atau kembali ke agama asalnya, maka perkawinan menjadi batal dan mereka harus dipisahkan karena suami menjadi murtad.

Dalam Islam, hukum dipandang sebagai bagian dari dari ajaran agama, dan norma-norma hukum bersumber pada agama. Umat Islam meyakini bahwa Hukum Islam berdasarkan wahyu Ilahi. Oleh karena itu, ia disebut Syariah, yang berarti jalan yang digariskan Tuhan untuk manusia. ${ }^{22}$

Syariah Islam memelihara dan menjaga nilai-nilai moral. Untuk tujuan ini, ada banyak ketentuan di dalam syariah untuk memelihara dan melindungi tia-tiap nilai moral. ${ }^{23}$

\section{Kedudukan Anak akibat Perkawinan Orang Tuanya yang Berbeda Agama}

Anak yang dilahirkan dari perkawinan seorang wanita muslimah dengan laki-laki non muslim dianggap anak tidak sah. Ketentuan ini didasarkan pada Fatwa MUI yang menyatakan bahwa wanita muslimah haram dan tidak sah secara mutlak menikah dengan laki-laki kafir, baik musyrik, ahli kitab, maupun yang lain. Jika dipaksakan maka pernikahannya dianggap batal dan tidak sah, demikian pula jika mereka melakukan hubungan suami istri maka hukumnya haram. ${ }^{24}$

Anak yang dilahirkan dari hubungan perkawinan antara laki-laki muslim dengan wanita non muslim dianggap tidak sah, karena pembolehan laki-laki menikah selain dengan wanita muslimah hanya kepada wanita ahli kitab. Saat ini disepakati tidak ada lagi ahli kitab, karena hampir setiap orang menyatakan diri sebagai pemeluk agama tertentu. Imam Syafi'i meriwayatkan bahwa Atha berkata : "Orang-orang Nasrani Arab bukanlah Ahli

\footnotetext{
${ }^{22}$ Moh. Lutfi Nurcahyono, Pembaruan Metode Penemuan Hukum Islam : Pendekatan Terpadu Hukum Islam dan Sosial, Jurnal Studi Keislaman "Ulumuna", Vol. 16 No. 1 (Juni) 2012, Institut Agama Islam Negeri Mataram, ISSN 1411-3457, hlm. 27

${ }^{23}$ Topo Santoso, Menggagas Hukum Pidana Islam : Penerapan Syariah Islam dalam Konteks Modernitas,
}

Kitab. Yang dikatakan Ahli Kitab hanyalah mereka yang berasal dari Bani Israel dan orang-orang yang diberikan kepada mereka Kitab Taurat dan Injil. Adapun orang yang masuk kepada agama mereka, tidak dianggap sebagai golongan mereka (Ahli Kitab). ${ }^{25}$

Dalam perkawinan orang tuanya yang berbeda agama, hubungan anak dengan orang tuanya memiliki banyak ketentuan yang antara lain : ${ }^{26}$

1) Jika bapaknya beragama Islam sedang ibunya bukan beragama Islam, maka selama ia belum memilih agama mana yang akan ia anut, ia akan dianggap mengikuti agama Bapaknya. Namun jika ternyata ketika dewasa ia memilih mengikuti agama ibunya yang bukan beragama Islam atau agama selain kedua orangtuanya (bukan beragama Islam) maka anak ini akan terputus hubungan nasabnya dengan orang tuanya yang beragama Islam (Bapaknya)

2) Jika Bapaknya bukan beragama Islam sedang ibunya beragama Islam, maka ia dianggap anak tidak sah, karena ia akan dibangsakan menurut keturunan bapaknya. Namun jika ternyata ketika dewasa ia memilih memeluk agama Islam, maka ia hanya memiliki hubungan nasab dengan ibunya yang beragama Islam saja, dan hubungan nasab (keturunan) antara ia dengan bapaknya terputus. ${ }^{27}$

Perwalian anak yang dilahirkan dari hubungan perkawinan antara lakilaki yang beragama Islam dengan wanita yang beragama selain Islam menjadi tanggung jawab dan berada di bawah penguasaan Bapaknya. Jika sang anak adalah seorang wanita, maka

Asy Syamil Press dan Grafika, Bandung, 2000, hlm. 81

${ }^{24}$ Majelis Ulama Indonesia, Op.Cit., hlm. 176

${ }^{25}$ Ibid.

${ }^{26}$ Abdul Muta'al al Jabri, Op. Cit., hlm. 43

27 Moh. Rifa'i, Ilmu Fiqh Islam Lengkap, CV. Toha Putra, Semarang, 1978, hlm. 512 
ketika ia akan menikah maka ayahnya (bapaknya) sah untuk menjadi wali nikahnya. Jika ia memilih agama selain Islam, maka perwaliannya tidak lagi ada pada bapaknya. Jika ia wanita maka wali nikahnya tidak bisa diwakilkan kepada ayahnya (bapaknya) karena perbedaan agama antara keduanya. Perwalian bagi anak yang dilahirkan dari hubungan perkawinan antara wanita yang beragama Islam dengan laki-laki yang beragama selain Islam hanya dikuasakan kepada ibunya saja. Anak yang dilahirkan dalam hubungan perkawinan ini hanya memiliki hubungan nasab dengan ibunya saja. ${ }^{28}$

Ahli Waris laki-laki maupun perempuan terhalang mendapat harta warisan jika terdapat salah satu sebab berikut, yaitu : ${ }^{29}$

1) Perbedaan Agama

2) Pembunuh

3) Budak

Berdasarkan fatwa MUI DKI Jakarta, ditetapkan hal-hal yang berhubungan dengan kewarisan sebagai berikut :

1) Berdasarkan ajaran Islam, sesudah kedua orangtua meninggal dunia, maka seluruh harta benda yang ditinggalkan menjadi hak milik keluarga yang menjadi ahli waris.

2) Harta peninggalan orangtua yang beragama Islam hanya bisa diwariskan kepada anak-anaknya yang beragama Islam pula dan tidak dapat diwarisi oleh anak-anaknya yang tidak beragama Islam.

Spesifikasi sistem hukum waris Islam menurut Al Quran salah satunya adalah Ahli Waris adalah orang yang berhak mewarisi karena hubungan kekerabatan (nasab) atau hubungan perkawinan (nikah) dengan pewaris, beragama Islam dan tidak terhalang karena hukum untuk menjadi ahli waris. ${ }^{30}$

Kata "beragama Islam" dalam hal ini tentu menegaskan bahwa selain beragama Islam tidak bisa menjadi Ahli Waris bagi Pewaris yang beragama Islam. Dengan begitu amat tegas dinyatakan pentingnya agama dalam pembagian harta waris.

\section{PENUTUP}

Kesimpulan

Berdasarkan uraian permasalahan tersebut di atas, maka dapat diuraikan kesimpulan sebagai berikut :

1. Bahwa berdasarkan Undang-Undang Perkawinan di Indonesia, perkawinan antar pemeluk agama yang berbeda dianggap tidak sah. Dalam hal ini Lakilaki muslim tetap dilarang menikah dengan Wanita nonmuslim, begitupun Wanita Muslimah dilarang menikah dengan Laki-laki Nonmuslim. Berdasarkan ketentuan Pasal 2 ayat (1) UU Nomor 1 Tahun 1974 maka perkawinan dianggap sah apabila dilakukan menurut agama dan kepercayaannya masing-masing. Momentum Perkawinan dikatakan sah, apabila telah dilangsungkan menurut hukum agama atau kepercayaannya masing-masing-masing.

2. Anak yang dilahirkan dari perkawinan seorang wanita muslimah dengan lakilaki non muslim dianggap anak tidak sah. Ketentuan ini didasarkan pada Fatwa MUI yang menyatakan bahwa wanita muslimah haram dan tidak sah secara mutlak menikah dengan lakilaki kafir, baik musyrik, ahli kitab, maupun yang lain. Jika dipaksakan maka pernikahannya dianggap batal dan tidak sah, demikian pula jika mereka melakukan hubungan suami istri maka hukumnya haram. Anak yang dilahirkan dari hubungan

\footnotetext{
${ }^{30}$ Rosnidar Sembiring, Op. Cit., hlm. 199
} 
perkawinan antara laki-laki muslim dengan wanita non muslim dianggap tidak sah, karena pembolehan laki-laki menikah selain dengan wanita muslimah hanya kepada wanita ahli kitab. Saat ini disepakati tidak ada lagi ahli kitab, karena hampir setiap orang menyatakan diri sebagai pemeluk agama tertentu.

Saran

Berdasarkan kesimpulan di atas, perlu dikemukakan beberapa saran sebagai berikut :

1. Diharapkan ada sosialisasi kembali secara berkala dan menyeluruh terkait dengan Perkawinan yang Berbeda Agama se awal mungkin. Lembaga Perkawinan beserta strukturalnya hendaknya lebih banyak menyampaikan dan memberi pemahaman mengenai hal ini.

2. Diharapkan Lembaga Perkawinan juga memberikan himbauan berkala dan berkelanjutan jika ternyata sudah terlanjur menemukan beberapa kasus kejadian terkait kedudukan anak yang Orangtuanya Berbeda Agama. Peran serta lembaga terkait dalam hal pemahaman dan perlindungan baik administrasi dan hak-hak sebagai subjek hukum amat berarti.

\section{DAFTAR PUSTAKA}

\section{Buku-buku}

Al Jabri, Abdul Muta'al. Apa Bahayanya Menikah dengan Wanita Nonmuslim? Tinjauan Fiqh dan Politik. Jakarta : Gema Insani Press, 2003

Eoh, O.S. Perkawinan antar Agama dalam Teori dan Praktek. Jakarta : PT. RajaGrafindo Persada, 2001

Halim, Abdul. Politik Hukum Islam di Indonesia : Kajian Posisi Hukum Islam dalam Politik Hukum Pemerintahan Orde Baru dan Era Reformasi. Seri Disertasi, Badan Litbang dan Diklat Departemen Agama RI, 2008
H. S., Salim dan Erlies Septiana Nurbaini. Perbandingan Hukum Perdata (Comparative Civil Law). Jakarta : PT. RajaGrafindo Persada, 2015

Rifa'i, Moh. Ilmu Fiqh Islam Lengkap. Semarang : CV. Toha Putra, 1978

Santoso, Topo. Menggagas Hukum Pidana Islam : Penerapan Syariah Islam dalam Konteks Modernitas. Bandung : Asy Syamil Press dan Grafika, 2000

Sembiring, Rosnidar. Hukum Keluarga (Harta-harta Benda dalam Perkawinan). Jakarta : PT. RajaGrafindo Persada, 2016

Zuhdi, Masjfuk. Masail Fiqhiyah. Jakarta : CV. Haji Mas Agung, 1998

Jurnal

Nurcahyono, Moh. Lutfi. Pembaruan Metode Penemuan Hukum Islam : Pendekatan Terpadu Hukum Islam dan Sosial. Jurnal Studi Keislaman "Ulumuna", Vol. 16 No. 1 (Juni) 2012, ISSN 1411-3457, Institut Agama Islam Negeri Mataram : 2012

M. Saerozi, Bila Negara Mengatur Agama, Jurnal Studi Islam dan Masyarakat "Ulumuna", Vol. VIII, Edisi 12, No. 2, Juli-Des 2003, Institut Agama Islam Negeri Mataram : 2003

Rokilah. Implikasi Kewarganegaraan Ganda bagi Warganegara Indonesia. Jurnal Ilmu Hukum "Ajudikasi”, Vol. 1 No. 2, Serang-Banten : Desember 2017

Peraturan Perundang-Undangan

Undang-Undang Nomor 1 Tahun 1974 tentang Perkawinan. Lembar Negara Tahun 1974 Nomor 1; Tambahan Lembar Negara Nomor 3019

Kompilasi Hukum Islam di Indonesia, Instruksi Presiden Nomor 1 Tahun 1991, Direktorat Pembinaan Badan Peradilan Agama Islam ; Direktorat Jenderal Pembinaan Kelembagaan Agama Islam; Departemen Agama Republik Indonesia, 2001

Majelis Ulama Indonesia, Fiqh Indonesia (Himpunan Fatwa-fatwa Aktual), Editor : M. Hamdan Rasyid, Al Mawardi Prima, Jakarta, 2003 
AJUDIKASI : Jurnal Ilmu Hukum, Vol. 2 No. 1, Juni 2018. Hlm 43-54 